\title{
Simulating the Impacts of Marine Organic Emissions on Global Atmospheric Chemistry and Aerosols Using an Online-Coupled Meteorology and Chemistry Model
}

\author{
Brett Gantt1,2, Timothy Glotfelty ${ }^{1}$, Nicholas Meskhidze', Yang Zhang ${ }^{1}{ }^{*}$ \\ ${ }^{1}$ Department of Marine, Earth, and Atmospheric Sciences, North Carolina State University, Raleigh, USA \\ ${ }^{2}$ Now at Office of Air Quality Planning and Standards, U.S. Environmental Protection Agency, Research Triangle \\ Park, Raleigh, USA \\ Email: *yang zhang@ncsu.edu
}

Received 4 June 2015; accepted 4 July 2015; published 7 July 2015

Copyright (C) 2015 by authors and Scientific Research Publishing Inc.

This work is licensed under the Creative Commons Attribution International License (CC BY).

http://creativecommons.org/licenses/by/4.0/

(c) (;) Open Access

\begin{abstract}
To realistically simulate the impacts of marine isoprene and primary organic aerosols (POA) on atmospheric chemistry, a unified model framework with online emissions, comprehensive treatment of gas-phase chemistry, and advanced aerosol microphysics is required. In this work, the global-through-urban WRF/Chem model (GU-WRF/Chem) implemented with the online emissions of marine isoprene and size-resolved marine POA is applied to examine such impacts. The net effect of these emissions was increased surface concentrations of isoprene and organic aerosols and decreased surfaced concentrations of hydroxyl radical and ozone over most marine regions. With the inclusion of these emissions, GU-WRF/Chem better predicted the surface concentrations of isoprene and organic aerosols and the aerosol number size distribution when compared to measurements in clean marine conditions.
\end{abstract}

\section{Keywords}

Marine Organic Emissions, Marine Organic Aerosol, Atmospheric Chemistry, Online-Coupled Model, GU-WRF/Chem

\section{Introduction}

The chemical composition and aerosols of the natural background atmosphere are important to model predictions

\footnotetext{
"Corresponding author.
}

How to cite this paper: Gantt, B., Glotfelty, T., Meskhidze, N. and Zhang, Y. (2015) Simulating the Impacts of Marine Organic Emissions on Global Atmospheric Chemistry and Aerosols Using an Online-Coupled Meteorology and Chemistry Model. Atmospheric and Climate Sciences, 5, 266-274. http://dx.doi.org/10.4236/acs.2015.53020 
of air quality and climate [1] [2]. Most models, however, have an incomplete emission inventory of natural marine aerosols and precursor gases beyond sea-salt aerosol and dimethyl sulfide. Two major emission types neglected from the default setting of many current models are biogenic volatile organic compounds (BVOCs) of marine origin and primary organic aerosol (POA) associated with sea spray. Isoprene is the most widely-reported BVOC species with a marine emission source [3] and has been shown to have a small impact on surface ozone $\left(\mathrm{O}_{3}\right)$ and secondary organic aerosol (SOA) formation in coastal regions [4]. Marine POA has been suggested to affect the surface aerosol mass concentration and cloud condensation nuclei (CCN) in remote marine regions [5]-[8]. However, large uncertainties in chemical composition [9] [10] and magnitude [11] [12] of sea spray aerosol have been shown to play an important role in determining the direct and indirect radiative forcing of marine aerosols [13]. Previous modeling efforts have included marine isoprene and POA emissions in several atmospheric chemistry [14]-[19] and online-coupled global climate models [6] [13] [20] [21].

In this study, we use the online-coupled global-through-urban weather and forecasting model with chemistry (GU-WRF/Chem) to quantify the impact of online emissions of marine isoprene and POA on atmospheric chemistry and aerosol abundance in remote marine and coastal regions. GU-WRF/Chem is capable of simulating these impacts across a wide range of spatial scales while reducing uncertainties from the use of offline-coupled model systems with inconsistent model treatments [22]. Comprehensive treatments of gas-phase chemistry and aerosol microphysics, in conjunction with online emissions of marine BVOC and POA, are expected to improve model predictions of surface concentrations of BVOCs, $\mathrm{O}_{3}$, and organic aerosols. The overall objective of this study is to estimate the impact of marine isoprene and POA emissions on remote marine atmospheric chemistry through comprehensive evaluation of model predictions against observations from marine regions.

\section{Model Description and Setup}

GU-WRF/Chem is developed upon the global WRF (GWRF) version 3.0 [23]-[26] and the mesoscale WRF/ Chem version 3.0 [27], and described in detail by Zhang et al. [22]. Simulations in this study are conducted with the 2005 Carbon Bond chemical mechanism with global extension (CB05_GE) [28]. The Model of Aerosol Dynamics, Reaction, Ionization, and Dissolution (MADRID) aerosol microphysics module [29] [30] used in GUWRF/Chem treats all major aerosol chemical and microphysical processes including inorganic aerosol thermodynamic equilibrium, SOA formation, nucleation, gas/particle mass transfer, condensation, and coagulation with eight size sections to represent the particle size distribution. MADRID was selected from among the three aerosol modules in this version of GU-WRF/Chem because it is the only one that treats isoprene as an SOA precursor. 32 aerosol types were considered in GU-WRF/Chem with anthropogenic and terrestrial emissions described in detail in Zhang et al. [22]. Model configurations not pertaining to chemistry were consistent with the baseline GWRF simulation described in Zhang et al. [26]. The model was reinitialized from the NCEP Final Global Data Assimilation System every 24 hours to allow meteorological feedbacks while constraining the simulation with re-initialized meteorological conditions based on observations.

Marine isoprene emissions implemented into GU-WRF/Chem were based on the parameterization developed by Gantt et al. [31], which experimentally determined that marine isoprene production is a function of phytoplankton abundance, speciation, and photosynthetically active radiation. Model implementation of marine isoprene emissions of Gantt et al. [31] has been previously described in detail in Gantt et al. [4], which uses the isoprene production rate for diatoms, model-predicted solar radiation, and Level 3 monthly average chlorophyll$a$ concentration ([Chl- $a]$ ) and diffuse attenuation coefficient derived from the Sea-viewing Wide Field-of- view Sensor (SeaWiFS) satellite to drive the emissions. Despite evidence for marine production of monoterpenes [32], this emission source was not included in GU-WRF/Chem due to the very low production rates relative to marine isoprene emissions [33]. Marine isoprene emissions were calculated online within GU-WRF/Chem and added to the existing terrestrial isoprene emissions of Guenther et al. [34].

Marine POA emissions implemented into GU-WRF/Chem were based on the parameterization developed by Gantt et al. [35]. These size-dependent aerosol emissions were based on the calculation of the organic mass fraction of sea spray aerosol $\left(\mathrm{OM}_{\mathrm{SSA}}\right)$, which Gantt et al. [35] found to be positively related to phytoplankton abundance and aerosol diameter and negatively related to surface wind speed. Within GU-WRF/Chem, OM $\mathrm{MSA}_{\mathrm{SSA}}$ was calculated online using monthly-mean SeaWiFS-derived [Chl- $a$ ] and model-predicted surface wind speed and applied to the existing sea spray emission module of Gong et al. [36] and O’Dowd et al. [37]. Model implementation of these emissions performed here was similar to the method described in detail by Meskhidze et 
al. [6]. The size-dependent mass and number emissions of marine POA were added online to the existing terrestrial POA based on the sectional size bins of MADRID in GU-WRF/Chem, with the atmospheric evolution of marine/terrestrial POA and SOA is simulated explicitly.

Two sets of GU-WRF/Chem simulations were performed: 1) the Default simulation without marine organic emissions and 2) the MarOrg simulation with marine isoprene and POA emissions described above. Each set of simulations was conducted over a 12-month period for two years (2001 and 2009) with a one-month spin-up for each year at a spatial resolution of $4^{\circ} \times 5^{\circ}$ and 27 vertical layers $\left(1^{\text {st }}\right.$ vertical layer height: $\left.35 \mathrm{~m}\right)$ up to $50 \mathrm{mb}$. These years were chosen for direct evaluation with field campaigns [38]-[40] measuring marine isoprene emissions and surface concentrations of isoprene and organic aerosols in remote marine environments. Other than the marine isoprene and POA emissions, all other chemical and meteorological model configurations for the Default and MarOrg simulations were kept constant.

\section{Results and Discussions}

\subsection{Trace Gases}

Figure 1 shows that marine isoprene emissions in the MarOrg simulation resulted in a change in surface isoprene concentrations from the simulation with default treatments over marine regions. The strong summertime solar radiation and high [Chl- $a$ ] levels in northern Atlantic and Pacific Oceans contributed to the high emission rates in those regions, while moderate ocean biological activity throughout the year over much of the Southern Ocean also resulted in high marine isoprene emission rates. Over remote marine regions, marine isoprene emissions increased surface isoprene concentrations by $5-10$ ppt (see Figure 1). This increase was within the range of most isoprene concentrations ( $<1$ to $300 \mathrm{ppt}$, typically $<50 \mathrm{ppt}$ ) observed over remote marine regions [3]. The large emission rates occurring near coastal regions (and some inland lakes) were due to the combination of isolated regions of very high [Chl- $a$ ] and coarse $\left(4^{\circ} \times 5^{\circ}\right)$ grid resolution. The greatest increases in surface isoprene concentrations were predicted over the northern Atlantic/Pacific and Southern Oceans where marine isoprene
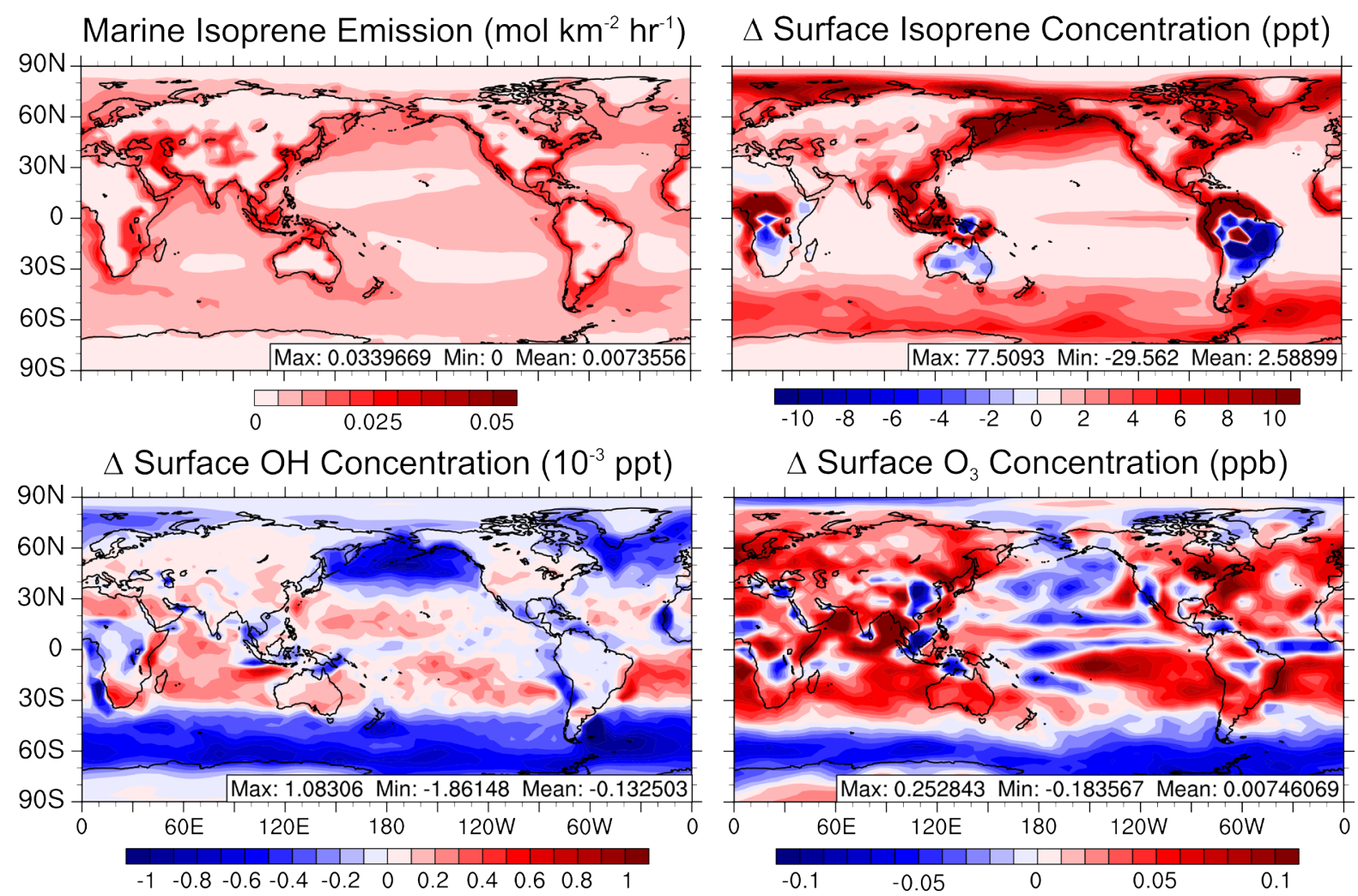

Figure 1. Multi-year (2001 and 2009) annual average marine isoprene emissions and differences in the predicted surface concentrations of isoprene, $\mathrm{OH}$, and $\mathrm{O}_{3}$ between the Default and MarOrg simulations. 
emission rates are high. These areas also had low oxidant levels and therefore long lifetimes of isoprene emitted from marine sources and transported from terrestrial regions. Over terrestrial areas such as the rainforests of South America, Southeast Asia, and Africa, a mixture of positive and negative changes in the surface isoprene concentrations is evident. Such changes were likely due to the fact that terrestrial emissions were computed online and were sensitive to the slight variability in meteorology occurring due to model reinitializations. Although the changes in surface isoprene concentrations over terrestrial areas were of similar magnitude as those of marine regions, they were much smaller when calculated in terms of percentage changes (typically $<5 \%$ ).

Predictions of other atmospheric chemistry-relevant gases in remote marine regions were also affected by emissions of marine isoprene. The surface concentrations of hydroxyl radical $(\mathrm{OH})$ decreased by $10^{-3} \mathrm{ppt}$ or more in parts of the northern Pacific and Southern Oceans(see Figure 1) because of its reaction with the additional isoprene from marine sources. Small changes in surface $\mathrm{O}_{3}$ concentration due to marine isoprene emissions(both increases and decreases of over $0.1 \mathrm{ppb}$ ) were also predicted; oceanic regions immediately downwind of anthropogenic pollution centers (China, U.S., etc.) experienced increased concentrations while remote marine regions typically have decreased concentrations (Figure 1). Decreases in predicted surface $\mathrm{O}_{3}$ concentrations over most of the eastern North Pacific Ocean were consistent with Gantt et al. [16], who found that the emission of isoprene and monoterpenes from marine sources caused a small $(-0.1 \%)$ decrease in CMAQ-predicted $\mathrm{O}_{3}$ mixing ratios off the Pacific coast of the U.S.

Although coincident measurements of isoprene emissions and concentrations over remote marine regions are very limited [3], the May 2001 simulation period allowed for model evaluation of predicted isoprene emissions/ concentrations in the northwest Pacific Ocean [38]. Compared to the Matsunaga et al. [38] observations, the model overpredicted marine isoprene emissions (especially during the daytime) and underpredicted surface concentrations (Figure 2). Concurrent over predictions of emissions and under predictions of surface concentrations suggested that the simulated isoprene lifetime by GU-WRF/Chem over the marine boundary layer was too short, potentially due to the coarse grid resolution. The low temporal resolution of the observed emissions in Matsunaga et al. [38] made a more quantitative analysis of the diurnal cycle of emissions difficult, but the few observations available were inconsistent with the large increase in daytime emissions predicted by the model. The very low surface isoprene concentrations predicted by the Default simulation do not support the suggestion from Matsunaga et al. [38] that terrestrial isoprene sources influence the surface concentrations in this region;

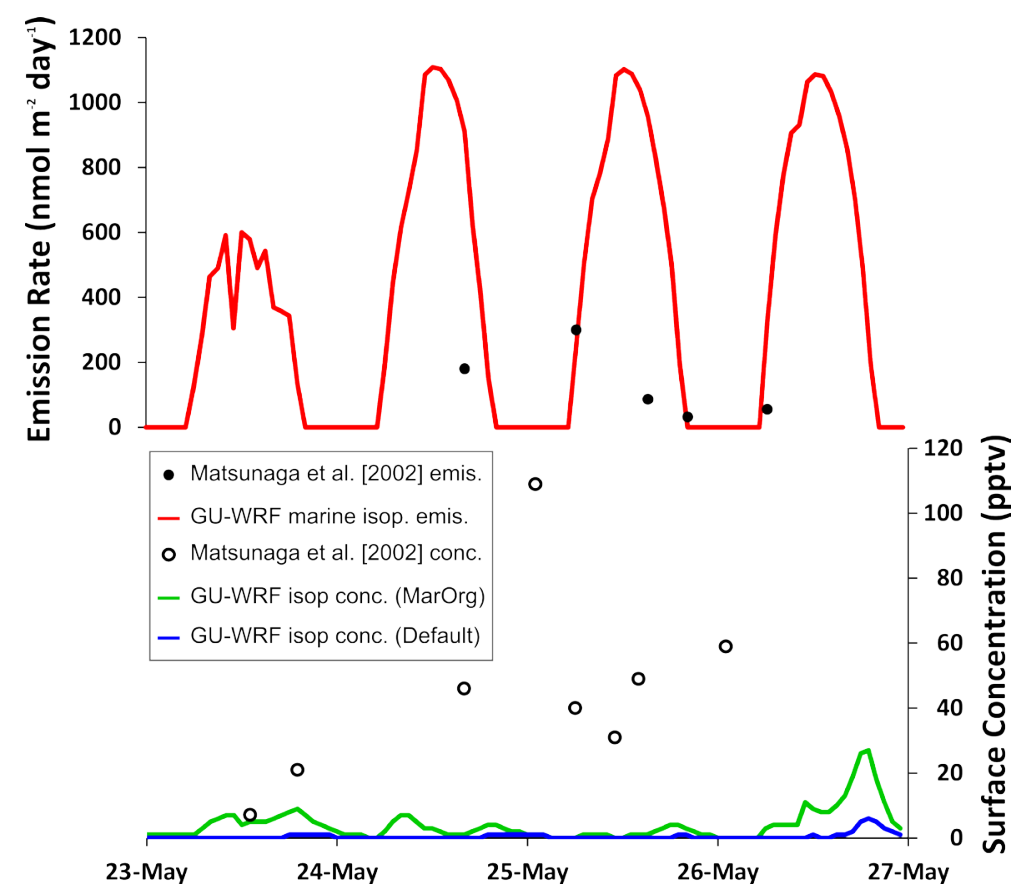

Figure 2. Time series comparison of observed [38] and modeled isoprene emissions (top) and surface concentrations (bottom) from the northwest Pacific Ocean in May 2001. 
although we cannot definitely rule out the possibility of terrestrial isoprene sources affecting surface concentrations because of the use of a coarse model grid resolution in our simulations, proximity to the Japanese coast $(\sim 500 \mathrm{~km})$ and the short isoprene lifetime predicted by GU-WRF/Chem in the marine boundary layer. The chemical mechanism used in GU-WRF/Chem, CB05-GE, is part of series developed for urban photochemistry [41] that may have difficulty representing remote marine conditions despite recent updates [38]. Nonetheless, according to Figure 2, the inclusion of marine isoprene emissions in the MarOrg simulation brought the predicted concentrations closer to observations.

\subsection{Aerosols}

Globally, the implementation of marine isoprene and POA emissions resulted in increased surface $\mathrm{PM}_{2.5}$ organic aerosol concentrations $\left(>0.5 \mu \mathrm{g} \cdot \mathrm{m}^{-3}\right.$ ) over biologically-active remote marine regions in the northern

Atlantic/Pacific and Southern Oceans (Figure 3). While the predicted increases in organic aerosol concentration occurred year-round in the Southern Ocean due to the persistent strong winds and moderate [Chl- $a$ ], increases in northern Atlantic and Pacific were the highest in the spring and lowest in the winter months. Surface organic aerosol concentrations in tropical oceanic regions were largely unchanged between the Default and Mar Org simulations due to low biological activity and sea spray aerosol emissions relative to mid- and high-latitude oceanic regions. Comparison of the predicted concentrations with observations in clean marine conditions compiled from the years 1973 to 2009 [9] indicated a latitudinal model bias, with over predictions in mid- and highlatitude regions and underpredictions in the tropics. Although only a few sites have measurements throughout the year (e.g., Mace Head, Amsterdam Island), comparison with model predictions in Figure 3 suggests that the MarOrg simulation did not replicate the observed seasonal cycle of concentrations. This result is consistent with Gantt et al. [42] who found that none of the existing sea spray aerosol-based marine POA emission parameterizations are able to replicate the observed seasonality of organic aerosol concentrations.

Comparison of GU-WRF/Chem and aerosol mass spectrometer observations from Mace Head, Ireland [39] for the year 2009 revealed that the inclusion of marine isoprene and POA emissions in the MarOrg simulation improved the prediction of surface submicron organic aerosol mass concentrations (see Figure 4). Without marine isoprene and POA emissions, the Default simulation frequently predicted surface organic aerosol concentrations
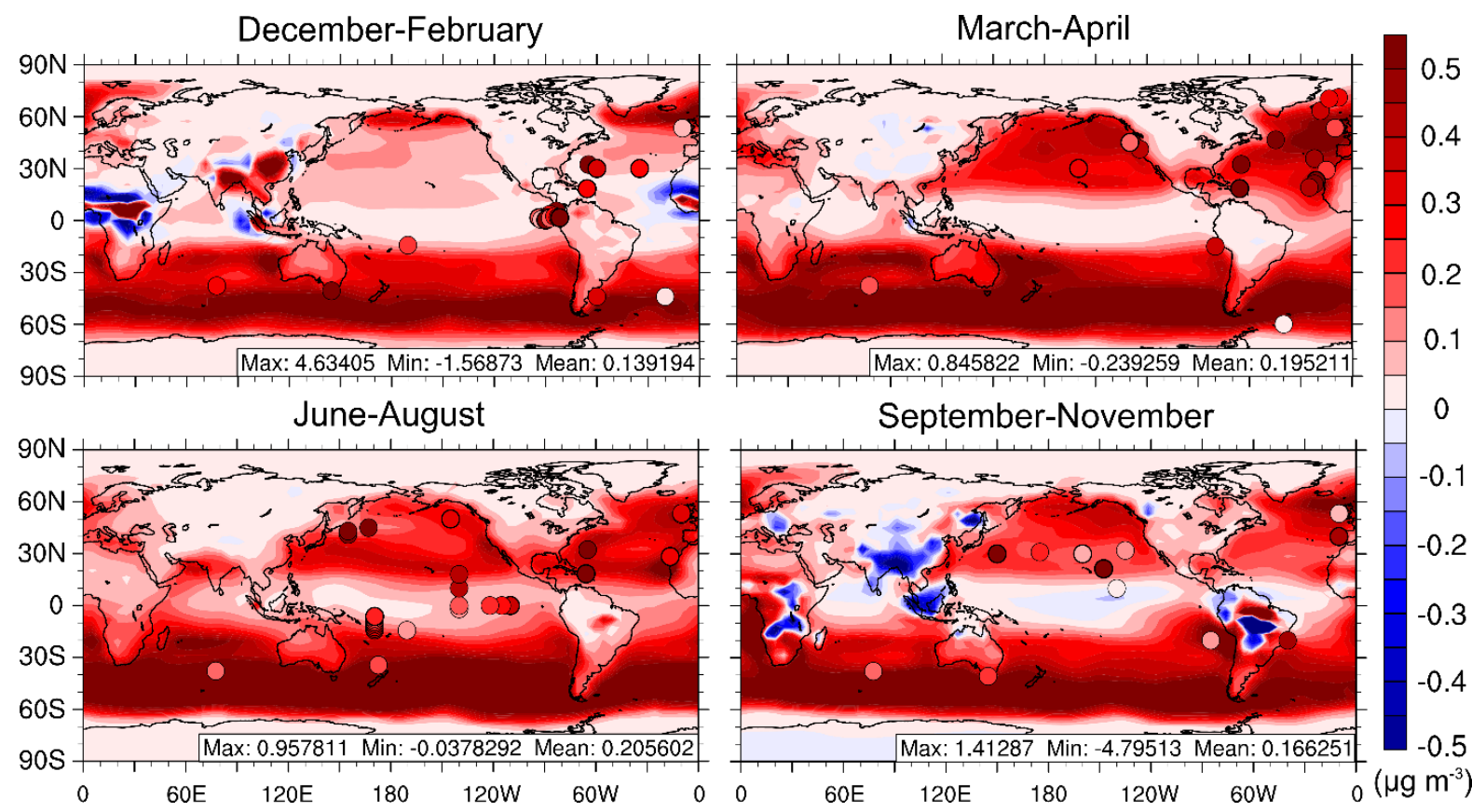

Figure 3. Multi-year (2001 and 2009) seasonally-averaged changes in the surface $\mathrm{PM}_{2.5}$ organic aerosol concentrations between the Default and MarOrg simulations superimposed with observed surface organic aerosol concentrations in clean marine conditions compiled by Gantt and Meskhidze [9]. 


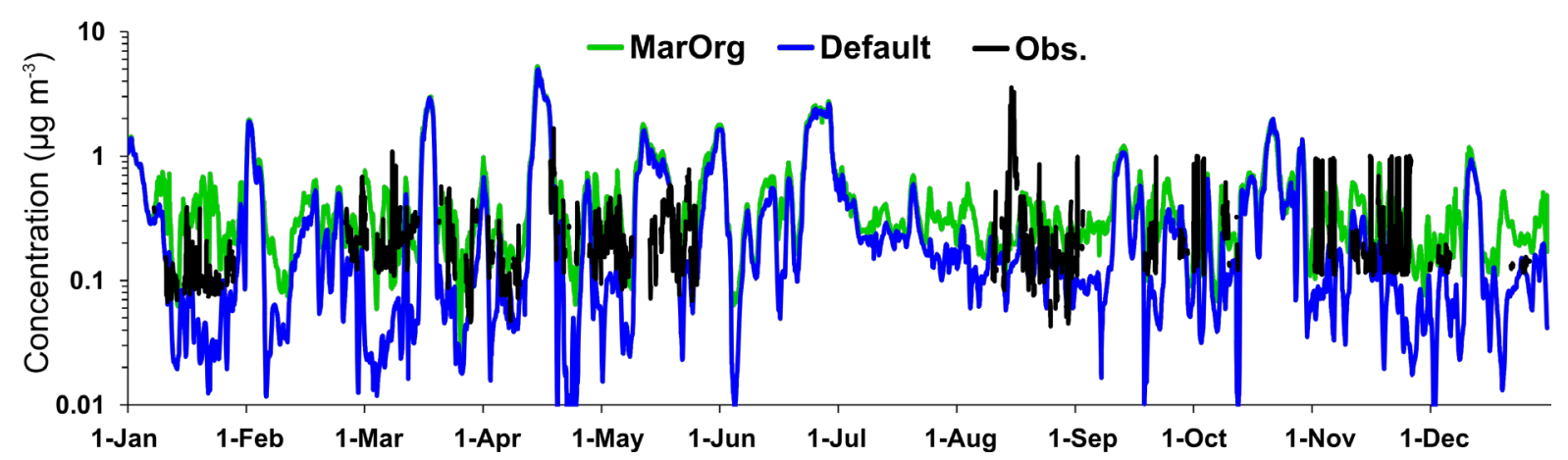

Figure 4. Time series comparison of modeled organic aerosol mass concentrations by GU-WRF/Chem with those observed at Mace Head, Ireland for the year 2009.

at Mace Head $<0.025 \mu \mathrm{g} \cdot \mathrm{m}^{-3}$ during clean marine conditions (defined as periods having aerosol number concentration $<700 \mathrm{~cm}^{-3}$, onshore wind direction, and black carbon concentrations $<0.05 \mu \mathrm{g} \cdot \mathrm{m}^{-3}$ ) while the observed concentrations typically ranged between 0.05 and $1 \mu \mathrm{g} \cdot \mathrm{m}^{-3}$ [39]. Organic aerosol concentrations rarely fell below $0.05 \mu \mathrm{g} \cdot \mathrm{m}^{-3}$ in the MarOrg simulation. Model-measurement discrepancies persisted in the MarOrg simulation, especially during the marine organic aerosol plume period (16 August 2009) observed by Ovadnevaite et al. [40]. During this plume event, the MarOrg simulation predicted organic aerosol concentrations (0.2 $\mu \mathrm{g} \cdot \mathrm{m}^{-3}$ ) that were an order of magnitude lower than the observed maximum concentrations $\left(3.8 \mu \mathrm{g} \cdot \mathrm{m}^{-3}\right)$. The change of annual average submicron organic (secondary and primary) aerosol concentrations at Mace Head between the Default and MarOrg simulations was $0.15 \mu \mathrm{g} \cdot \mathrm{m}^{-3}$, a value similar to the observed annual concentrations $\left(0.25 \mu \mathrm{g} \cdot \mathrm{m}^{-3}\right)$ at Mace Head during clean marine conditions.

During the marine organic aerosol plume (16 August 2009) observed by Ovadnevaite et al. [40] (see Figure 5), the MarOrg simulation had a slightly higher aerosol number concentration than the Default simulation in the size range over which both simulations had the largest underpredictions ( 0.05 to $0.5 \mu \mathrm{m}$ in diameter) relative to observations. Much of this difference is attributable to the increased organic aerosol number concentrations for diameters $>0.05 \mu \mathrm{m}$. In other clean marine periods where the MarOrg and Default simulations predicted substantially different submicron organic aerosol mass concentrations, the increase in the aerosol number concentration for the MarOrg simulation in the 0.05 to $0.5 \mu \mathrm{m}$ diametersize range is more evident. These model results are consistent with the observations of multiple marine organic aerosol plumes from Ovadnevaite et al. [40], who found that periods with the highest mass fraction of organics in submicron aerosols also had aerosol number size distributions peaking between 0.05 and $0.2 \mu \mathrm{m}$ in diameter. It's clear, however, that the MarOrg simulation did not accurately simulate this marine organic aerosol plume both in terms of magnitude and size distribution.

\section{Conclusion}

In this study, we implemented marine isoprene and size-resolved marine POA emissions into GU-WRF/Chem, an online-coupled meteorology and chemistry model. The resulting increases in the surface concentrations of isoprene and organic aerosols over remote marine regions led to small decreases in the surface concentration of $\mathrm{OH}$ and $\mathrm{O}_{3}$ and brought the model predictions into better agreement with isoprene emissions and surface concentrations in the northwest Pacific Ocean. Predictions of the aerosol number size distribution during an observed marine organic aerosol plume were also improved when these emissions were included. Although the inclusion of these emission sources did not bring the model into complete agreement with observed concentrations of isoprene and organic aerosols in remote marine regions, the improved predictions suggested that these emissions are important processes affecting atmospheric chemistry in these areas. As many coastal cities experience periods when clean marine conditions impact the background concentrations of pollutants, the inclusion of these marine emissions would benefit future air quality studies. The improved representation of aerosol number size distributions in clean marine conditions may also benefit the prediction of cloud condensation nuclei concentrations and associated cloud properties for future climate studies. 


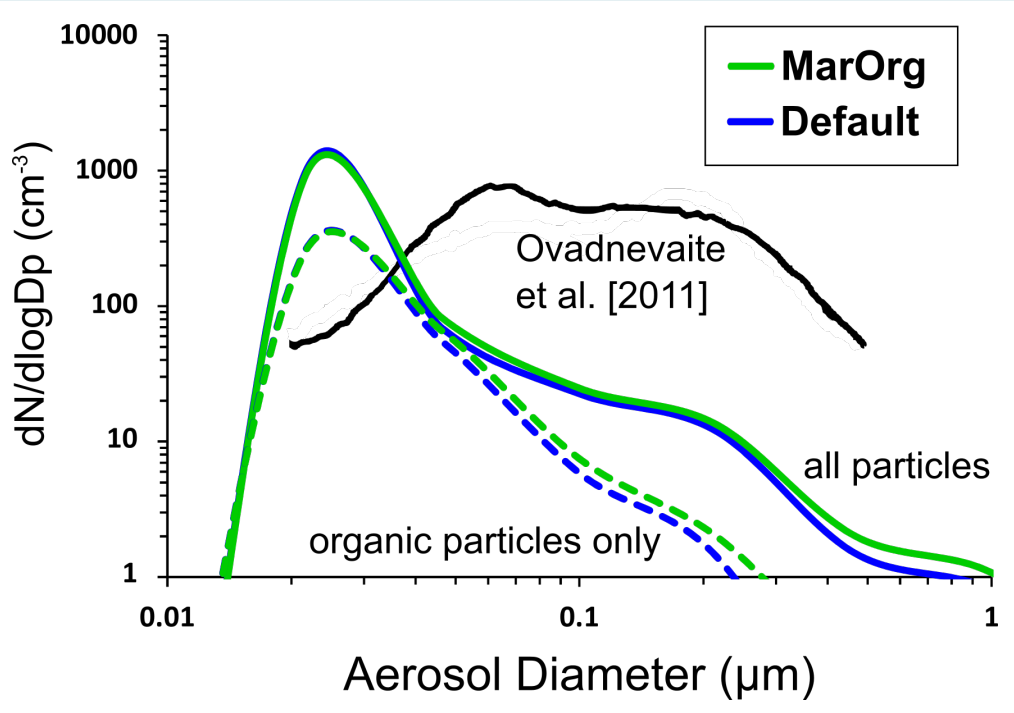

Figure 5. Observed [39] and predicted aerosol size distribution for the Default and MarOrg simulations on 16 August 2009. For reference, the organic aerosol size distribution for both simulations is given by the dotted lines. Note that the sectional size distribution predicted by MADRID in GU-WRF/Chem has been mapped to a modal size distribution through smoothing to better compare with observations.

\section{Acknowledgements}

This project was sponsored by the U.S. Department of Energy grant \#DE-FG02-08ER64508, the EPA STAR grant R83337601, and the National Science Foundation EaSM program (AGS-1049200). We also thank Jurgita Ovadnevaite, Darius Ceburnis, and Colin O’Dowd for providing the Mace Head data.

\section{References}

[1] Lohmann, U., Feichter, J., Penner, J. and Leaitch, R. (2000) Indirect Effect of Sulfate and Carbonaceous Aerosols: A Mechanistic Treatment. Journal of Geophysical Research, 105, 12193-12206. http://dx.doi.org/10.1029/1999JD901199

[2] Fiore, A.M., Jacob, D.J., Bey, I., et al. (2002) Background Ozone over the United States in Summer: Origin, Trend, and Contribution to Pollution Episodes. Journal of Geophysical Research, 107, 2156-2202. http://dx.doi.org/10.1029/2001jd000982

[3] Shaw, S.L., Gantt, B. and Meskhidze, N. (2010) Production and Emissions of Marine Isoprene and Monoterpenes: A Review. Advances in Meteorology, 2010, Article ID: 408696. http://dx.doi.org/10.1155/2010/408696

[4] Gantt, B., Meskhidze, N., Zhang, Y. and Xu, J. (2010) The Effect of Marine Isoprene Emissions on Secondary Organic Aerosol and Ozone Formation in the Coastal United States. Atmospheric Environment, 44, 115-121. http://dx.doi.org/10.1016/j.atmosenv.2009.08.027

[5] O’Dowd, C.D., Facchini, M.C., Cavalli, F., et al. (2004) Biogenically Driven Organic Contribution to Marine Aerosol. Nature, 431, 676-680. http://dx.doi.org/10.1038/nature02959

[6] Meskhidze, N., Xu, J., Gantt, B., et al. (2011) Global Distribution and Climate Forcing of Marine Organic Aerosol: 1. Model Improvements and Evaluation. Atmospheric Chemistry and Physics, 11, 11689-11705.

http://dx.doi.org/10.5194/acp-11-11689-2011

[7] Collins, D.B., Ault, A.P., Moffet, R.C., et al. (2013) Impact of Marine Biogeochemistry on the Chemical Mixing State and Cloud Forming Ability of Nascent Sea Spray Aerosol. Journal of Geophysical Research, 118, 8553-8565. http://dx.doi.org/10.1002/jgrd.50598

[8] Hu, Q.-H., Xie, Z.-Q., Wang, X.-M., et al. (2013) Secondary Organic Aerosols over Oceans via Oxidation of Isoprene and Monoterpenes from Arctic to Antarctic. Scientific Reports, 3, Article Number: 2280. http://dx.doi.org/10.1038/srep02280

[9] Gantt, B. and Meskhidze, N. (2013) The Physical and Chemical Characteristics of Marine Primary Organic Aerosol: A Review. Atmospheric Chemistry and Physics, 13, 3979-3996. http://dx.doi.org/10.5194/acp-13-3979-2013 
[10] Prather, K.A., Bertram, T.H., Grassian, V.H., et al. (2013) Bringing the Ocean into the Laboratory to Probe the Chemical Complexity of Sea Spray Aerosol. Proceedings of the National Academy of Sciences of the United States of America, 110, 7550-7555. http://dx.doi.org/10.1073/pnas.1300262110

[11] Lewis, E.R. and Schwartz, S.E. (2004) Sea Salt Aerosol Production: Mechanisms, Methods, Measurements and Models -A Critical Review. Geophysical Monograph Series, 152, 413. http://dx.doi.org/10.1029/gm152

[12] de Leeuw, G., Andreas, E.L., Anguelova, M.D., Fairall, C.W., Lewis, E.R., O’Dowd, C., et al. (2011) Production Flux of Sea Spray Aerosol. Reviews of Geophysics, 49, Article ID: RG2001. http://dx.doi.org/10.1029/2010RG000349

[13] Tsigaridis, K., Koch, D.M. and Menon, S. (2013) Uncertainties and Importance of Sea-Spray Composition on Aerosol Direct and Indirect Effects. Journal of Geophysical Research, 118, 220-235. http://dx.doi.org/10.1029/2012jd018165

[14] O’Dowd, C.D., Langmann, B., Varghese, S., Scannell, C., Ceburnis, D. and Facchini, M.C. (2008) A Combined Organic-Inorganic Sea-Spray Source Function. Geophysical Research Letters, 35, Article ID: L01801. http://dx.doi.org/10.1029/2007GL030331

[15] Arnold, S.R., Spracklen, D.V., Williams, J., Yassaa, N., Sciare, J., Bonsang, B., et al. (2009) Evaluation of the Global Oceanic Isoprene Source and Its Impacts on Marine Organic Carbon Aerosol. Atmospheric Chemistry and Physics, 9, 1253-1262. http://dx.doi.org/10.5194/acp-9-1253-2009

[16] Gantt, B., Meskhidze, N. and Carlton, A.G. (2010) The Contribution of Marine Organics to the Air Quality of the Western United States. Atmospheric Chemistry and Physics, 10, 7415-7423. http://dx.doi.org/10.5194/acp-10-7415-2010

[17] Anttila, T., Langmann, B., Varghese, S. and O’Dowd, C. (2010) Contribution of Isoprene Oxidation Products to Marine Aerosol over the North-East Atlantic. Advances in Meteorology, 2010, Article ID: 482603. http://dx.doi.org/10.1155/2010/482603

[18] Myriokefalitakis, S., Vignati, E., Tsigaridis, K., Papadimas, C., Sciare, J., Mihalopoulos, N., et al. (2010) Global Modeling of the Oceanic Source of Organic Aerosols. Advances in Meteorology, 2010, Article ID: 939171. http://dx.doi.org/10.1155/2010/939171

[19] Vignati, E., Facchini, M.C., Rinaldi, M., Scannell, C., Ceburnis, D., Sciare, J., et al. (2010) Global Scale Emission and Distribution of Sea-Spray Aerosol: Sea-Salt and Organic Enrichment. Atmospheric Environment, 44, 670-677. http://dx.doi.org/10.1016/j.atmosenv.2009.11.013

[20] Long, M.S., Keene, W.C., Kieber, D.J., Erickson, D.J. and Maring, H. (2011) A Sea-State Based Source Function for Size- and Composition-Resolved Marine Aerosol Production. Atmospheric Chemistry and Physics, 11, 1203-1216. http://dx.doi.org/10.5194/acp-11-1203-2011

[21] Westervelt, D.M., Moore, R.H., Nenes, A. and Adams, P.J. (2012) Effect of Primary Organic Sea Spray Emissions on Cloud Condensation Nuclei Concentrations. Atmospheric Chemistry and Physics, 12, 89-101. http://dx.doi.org/10.5194/acp-12-89-2012

[22] Zhang, Y., Karamchandani, P., Glotfelty, T., Streets, D.G., Grell, G., Nenes, A., et al. (2012) Development and Initial Application of the Global-through-Urban Weather Research and Forecasting Model with Chemistry (GU-WRF/Chem). Journal of Geophysical Research, 117, Article ID: D20206.

[23] Richardson, M.I., Toigo, A.D. and Newman, C.E. (2005) Non-Conformal Projection, Global, and Planetary Versions of WRF. Proceedings of the 2005 Joint WRF/MM5 User's Workshop, Mesoscale and Microscale Meteorology Division, National Center for Atmospheric Research, Boulder, 27-30 June 2005, Paper \#7.1.

[24] Richardson, M.I., Toigo, A.D. and Newman, C.E. (2007) Planet WRF: A General Purpose, Local to Global Numerical Model for Planetary Atmosphere and Climate Dynamics. Journal of Geophysical Research, 112, Article ID: E09001. http://dx.doi.org/10.1029/2006je002825

[25] Skamarock, W.C., Klemp, J.B., Dudhia, J., et al. (2008) A Description of the Advanced Research WRF Version 3, Tech. Note, NCAR/TN-475+STR. National Center for Atmospheric Research, Boulder.

[26] Zhang, Y., Hemperly, J., Meskhidze, N. and Skamarock, W.C. (2012) The Global Weather Research and Forecasting (GWRF) Model: Model Evaluation, Sensitivity Study, and Future Year Simulation. Atmospheric and Climate Sciences, 2, 231-253. http://dx.doi.org/10.4236/acs.2012.23024

[27] Grell, G.A., Peckham, S.E., Schmitz, R., McKeen, S.A., Frost, G., Skamarock, W.C. and Eder, B. (2005) Fully Coupled “Online” Chemistry within the WRF Model. Atmospheric Environment, 39, 6957-6975. http://dx.doi.org/10.1016/j.atmosenv.2005.04.027

[28] Karamchandani, P., Zhang, Y., Chen, S.Y. and Balmori-Bronson, R. (2012) Development and Testing of an Extended Chemical Mechanism for Global-through-Urban Applications. Atmospheric Pollution Research, 3, 1-24.

[29] Zhang, Y., Pun, B., Vijayaraghavan, K., Wu, S.Y., Seigneur, C., Pandis, S.N., et al. (2004) Development and Application of the Model of Aerosol Dynamics, Reaction, Ionization and Dissolution (MADRID). Journal of Geophysical Re- 
search, 109, Article ID: D01202. http://dx.doi.org/10.1029/2003jd003501

[30] Zhang, Y., Pan, Y., Wang, K., Fast, J.D. and Grell, G.A. (2010) WRF/Chem-MADRID: Incorporation of an Aerosol Module into WRF/Chem and Its Initial Application to the TexAQS2000 Episode. Journal of Geophysical Research, 115, Article ID: D18202. http://dx.doi.org/10.1029/2009jd013443

[31] Gantt, B., Meskhidze, N. and Kamykowski, D. (2009) A New Physically-Based Quantification of Marine Isoprene and Primary Organic Aerosol Emissions. Atmospheric Chemistry and Physics, 9, 4915-4927. http://dx.doi.org/10.5194/acp-9-4915-2009

[32] Yassaa, N., Peeken, I., Zöllner, E., Bluhm, K., Arnold, S., Spracklen, D. and Williams, J. (2008) Evidence for Marine Production of Monoterpenes. Environmental Chemistry, 5, 391-401. http://dx.doi.org/10.1071/EN08047

[33] Meskhidze, N., Sabolis, A., Reed, R. and Kamykowski, D. (2015) Quantifying Environmental Stress-Induced Emissions of Algal Isoprene and Monoterpenes Using Laboratory Measurements. Biogeosciences, 12, 637-651. http://dx.doi.org/10.5194/bg-12-637-2015

[34] Guenther, A., Zimmerman, P., Harley, P., Monson, R. and Fall, R. (1993) Isoprene and Monoterpene Emission Rate Variability: Model Evaluation and Sensitivity Analysis. Journal of Geophysical Research, 98, 12609-12617. http://dx.doi.org/10.1029/93JD00527

[35] Gantt, B., Meskhidze, N., Facchini, M.C., Rinaldi, M., Ceburnis, D. and O’Dowd, C.D. (2011) Wind Speed Dependent Size-Resolved Parameterization for the Organic Mass Fraction of Sea Spray Aerosol. Atmospheric Chemistry and Physics, 11, 8777-8790. http://dx.doi.org/10.5194/acp-11-8777-2011

[36] Gong, S., Barrie, L.A. and Blanchet, J.P. (1997) Modeling Sea Salt Aerosols in the Atmosphere: 1. Model Development. Journal of Geophysical Research, 102, 3805-3818. http://dx.doi.org/10.1029/96JD02953

[37] O’Dowd, C.D., Michael, H.S., Consterdine, I.E. and Lowe, J.A. (1997) Marine Aerosol, Sea-Salt, and the Marine Sulphur Cycle: A Short Review. Atmospheric Environment, 31, 73-80. http://dx.doi.org/10.1016/s1352-2310(96)00106-9

[38] Matsunaga, S., Mochida, M., Saito, T. and Kawamura, K. (2002) In Situ Measurement of Isoprene in the Marine Air and Surface Seawater from the Western North Pacific. Atmospheric Environment, 36, 6051-6057. http://dx.doi.org/10.1016/S1352-2310(02)00657-X

[39] Ovadnevaite, J., O’Dowd, C., Dall’Osto, M., Ceburnis, D., Worsnop, D.R. and Berresheim, H. (2011) Detecting High Contributions of Primary Organic Matter to Marine Aerosol: A Case Study. Geophysical Research Letters, 38, Article ID: L02807. http://dx.doi.org/10.1029/2010gl046083

[40] Ovadnevaite, J., Ceburnis, D., Martucci, G., Bialek, J., Monahan, C., Rinaldi, M., et al. (2011) Primary Marine Organic Aerosol: A Dichotomy of Low Hygroscopicity and High CCN Activity. Geophysical Research Letters, 38, Article ID: L21806. http://dx.doi.org/10.1029/2011GL048869

[41] Gery, M.W., Whitten, G.Z., Killus, J.P. and Dodge, M.C. (1989) A Photochemical Kinetics Mechanism for Urban and Regional Scale Computer Modeling. Journal of Geophysical Research, 94, 12925-12956. http://dx.doi.org/10.1029/JD094iD10p12925

[42] Gantt, B., Johnson, M.S., Meskhidze, N., Sciare, J., Ovadnevaite, J., Ceburnis, D. and O’Dowd, C.D. (2012) Model Evaluation of Marine Primary Organic Aerosol Emission Schemes. Atmospheric Chemistry and Physics, 12, 85538566. http://dx.doi.org/10.5194/acp-12-8553-2012 